\title{
Phylogenetic model of Follicucullus lineages (Albaillellaria, Radiolaria) based on high-resolution biostratigraphy of the Permian Bancheng Formation, Guangxi, South China
}

\author{
LEI ZHANG ${ }^{1,2}$, TSUYOSHI ITO ${ }^{1}$, QINGLAI FENG ${ }^{1 *}$, MARTIAL CARIDROIT $^{2}$ \& TANIEL DANELIAN ${ }^{2}$ \\ ${ }^{1}$ State Key Laboratory of Geological Processes and Mineral Resources, China University of Geosciences, Wuhan 430074, China \\ ${ }^{2}$ University Lille 1, Géosystèmes (UMR 8217 CNRS/Lille1), Department of Earth Sciences, Bât SN5, 59655 Villeneuve d'Ascq cedex, France \\ *Corresponding author (e-mail: qinglaifeng@cug.edu.cn)
}

\begin{abstract}
High-resolution sampling was performed on four Permian sections in Guangxi Province, South China (Gujingling, Sanpaoling, Guoyuan and Yutouling sections). We report abundant and well-preserved Guadalupian-Lopingian radiolarian assemblages, with 25 species belonging to three genera of the order Albaillellaria. Among them, the most abundant genus is Follicucullus with 17 species: F. bipartitus, F. charveti, F. sp. cf. F. charveti, F. dilatatus, F. falx, F. sp. cf. F. falx, F. guangxiensis, F. hamatus, F. monacanthus, $F$. sp. cf. $F$. monacanthus, $F$. orthogonus, $F$. sp. cf. F. orthogonus, $F$. porrectus, $F$. scholasticus, $F$. sp. cf. $F$. scholasticus, $F$. ventricosus and $F$. sp. cf. $F$. ventricosus. On the basis of composite stratigraphic ranges, this study suggests four Interval Zones in ascending order, namely F. monacanthus, F. porrectus, F. scholasticus and F. charveti Interval Zones. We provide a phylogenetic model for Follicucullus based on their morphological affinities and stratigraphic distribution. The genus Follicucullus originated from Pseudoalbaillella fusiformis, with $F$. monacanthus as the forerunner species from which two contemporary species then radiated: $F$. dilatatus and $F$. porrectus. Follicucullus porrectus is a long-lasting species, it is abundant in our material and several Follicucullus lineages originated from it. In terms of evolution it is considered to be the ancestor of a number of Follicucullus species.
\end{abstract}

SUPPLEMENTARY MATERIAL: Systematic palaeontology of Follicucullus is available at http://www. geolsoc.org.uk/SUP18772

KEYWORDS: Permian, Radiolaria, Follicucullus, taxonomy, phylogenetic model, interval biozones

\section{INTRODUCTION}

The radiolarian genus Follicucullus, known from the GuadalupianLopingian (Permian) and the Lower Triassic, is very interesting to palaeontologists because of its simple morphology, relatively rapid evolution and worldwide distribution. It was originally described from the Guadalupian of the Delaware Basin (Texas, USA), where two species were recognized: $F$. scholasticus (type-species) and F. ventricosus (Ormiston \& Babcock, 1979). Six new species were later described from the Guadalupian and/or Lopingian of Japan: F. monacanthus (Guadalupian; Ishiga et al., 1982b), $F$. bipartitus, F. charveti, F. falx, F. hamatus and F. orthogonus (Guadalupian-Lopingian; Caridroit \& De Wever, 1984). The species $F$. dilatatus, $F$. lagenarius and $F$. porrectus were established by Rudenko (in Belyanskiy et al., 1984) and, more recently, F. guangxiensis was described from the Wuchiapingian (Lower Lopingian) of the Guangxi Province, China (Wang et al., 2012).

Caridroit \& De Wever (1986) discussed the phylogeny of Follicucullus species in the Lopingian and documented the position of most members in a phylogenetic tree. They recognized two lineages: (i) F. scholasticus giving rise to $F$. furca and F. bipartitus, the latter evolving further up into F. hamatus; (ii) F. ventricosus giving rise to $F$. orthogonus and $F$. charveti, the latter evolving further up into $F$. falx. Based on morphology, Ishiga (1991) and Feng \& Liu (1993) studied the relationships of F. scholasticus (Ormiston \& Babcock, 1979), F. ventricosus and F. latior (Feng \& Liu, 1993) and suggested the existence of three evolutionary lineages associated with each of these species. The relationship between genera Pseudoalbaillella and Follicucullus was later established by De Wever et al. (2001) on the basis of morphological affinities. Xia et al. (2005) illustrated three main lineages of Follicucullus (the divergence of $F$. monacanthus from a Pseudoalbaillella stock, the $F$. bipartitus $-F$. scholasticus$F$. porrectus lineage, and the $F$. porrectus $-F$. ventricosus $-F$. charveti-F. falx lineage). However, these proposed lineages need to be revised because several nomen nudum species are depicted. More recently, the conclusions reached by Wang et al. (2012) differ slightly from those of Caridroit \& De Wever (1986), as they recognize three lineages: (i) F. scholasticus giving rise to $F$. porrectus (Rudenko in Belyanskiy et al., 1984), F. furca (Cardroit \& De Wever, 1986) and F. hamatus (Cardroit \& De Wever, 1984), and the latter to $F$. bipartitus, (ii) $F$. porrectus giving rise to $F$. guangxiensis and $F$. ventricosus; (iii) $F$. ventricosus giving rise to $F$. charveti, F. falx, and F. orthogonus. However, phylogenetic relationships within these three evolutionary lineages are still in dispute, mostly because key intermediate morphotypes have not yet been documented. In addition, regarding the Follicucullusbased biostratigraphy, three Assemblage Zones are known for the Guadalupian-Lopingian interval: these are, in chronological order, the F. monacanthus, F. scholasticus and F. bipartitus-F. charveti Assemblage Zones (Ishiga et al., 1982a; Ishiga, 1990). However, the full biostratigraphic potential of Follicucullus evolutionary lineages has not yet been exploited, and will benefit from the definition of evolutionary bioevents that will constrain the lower and upper limits of Interval Zones.

To improve phylogenetic and biostratigraphic knowledge of Guadalupian-Lopinginan radiolarian diversity and evolution, four sections situated in the Xiaodong area, southern Guangxi, China, were carefully studied and sampled (Fig. 1). We report here abundant and diverse assemblages from Guadalupian to Lower Lopingian units recording the complete evolution of the genus 


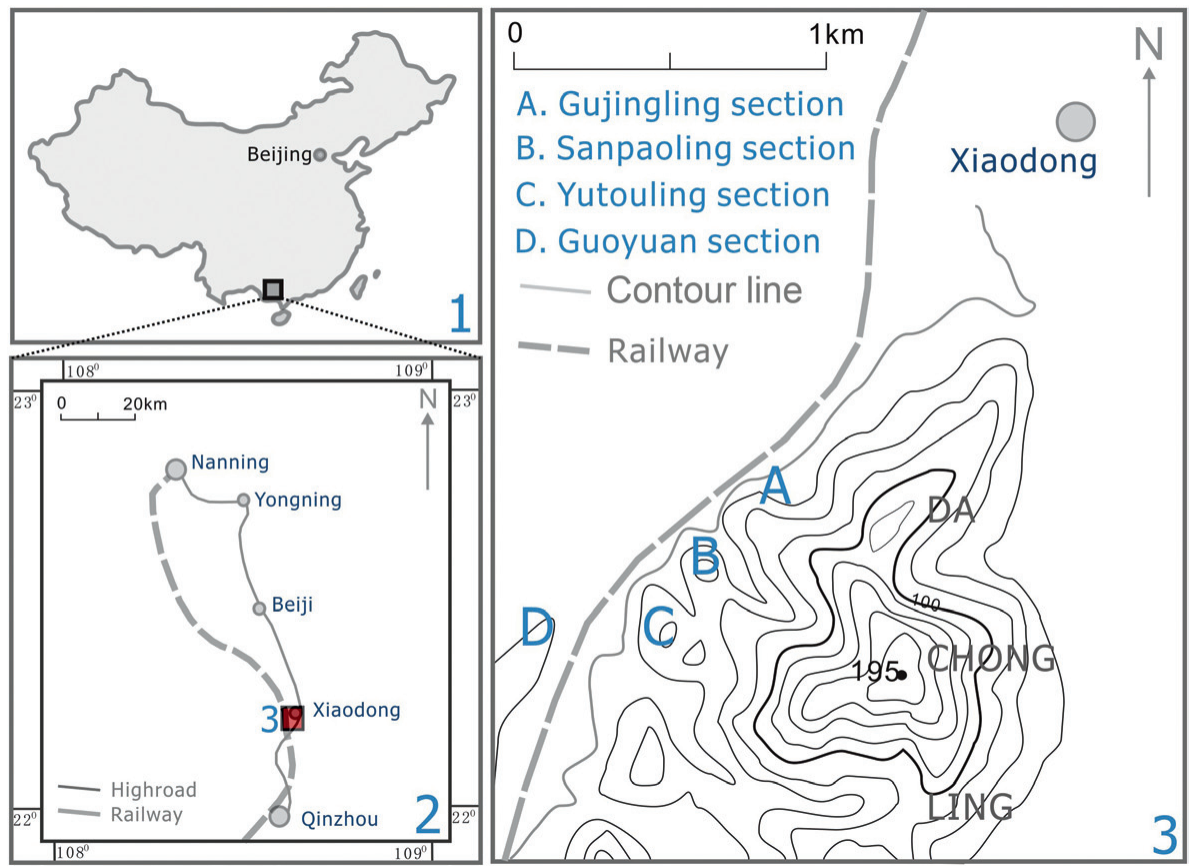

Fig. 1. Maps of the studied area: (1) geographical map of China; (2) enlargement of the Southern Guangxi area - the square illustrates the studied locality; (3) detailed topographic map of the four sections sampled for this work (see Fig. 2).

Follicucullus, from its appearance to disappearance. Radiolarian abundance and diversity are very high in these localities, and many intermediate forms between distinct Follicucullus species have been recovered. These morphotypes provide the opportunity to put forward a novel phylogenetic model for this genus. They also provide key data to clarify and specify the Follicucullusbased biostratigraphy.

STRATIGRAPHIC SETTING, MATERIAL AND METHODS In southeastern Guangxi, the Bancheng Formation is composed of grey-yellow and brown-grey thinly bedded siliceous rocks, muddy siliceous rocks, siliceous shales and mudstones (Bureau of Geology and Mineral Resources of Guangxi Autonomous Region, 1997). The Bancheng Formation belongs to the Qinzhou allochthon and contains Late Carboniferous-Lopingian radiolarian fossils (e.g. Wang et al., 1998; Ito et al., 2013).

The Guadalupian-Lopingian series of the Bancheng Formation was sampled in four sections (Gujingling, Sanpaoling, Guoyuan and Yutouling) located in the Dachongling region, south of Xiaodong town, $28 \mathrm{~km}$ north of Qinzhou city, Guangxi Province, China (Fig. 1). All samples were processed with hydrofluoric acid (concentration 4\%); productive samples yielded well-preserved and very abundant radiolarian specimens. In the scope of our discussion, we list only the species of Follicucullus and Pseudoalbailella; the complete faunal list of the studied sections is work in progress. The systematic descriptions and discussion of all species of Follicucullus found in these four sections are given at the end of this article.

The Gujingling (GJL) section is about $26 \mathrm{~m}$ thick, subdivided into 16 units. In the lower part $(8.57 \mathrm{~m}$; unit 1 to base of unit 5) there are thinly bedded red to yellow-red silty cherts, with occasional thinly bedded mudstones. The middle part
( $1.81 \mathrm{~m}$; unit 5) comprises thickly bedded siltstones with abundant clay minerals. The upper part $(15.31 \mathrm{~m}$; units 6 to 16$)$ consists of red to yellow-red cherts and yellow to yellow-brown siliceous siltstones, with occasional layers of tuff and mudstone. Some 154 samples were collected, of which 143 were productive and yielded four Pseudoalbaillella and nine Follicucullus species (Fig. 2A).

The Sanpaoling (SPL) section is about $20 \mathrm{~m}$ thick, subdivided into 8 units. The lower part (about $7.8 \mathrm{~m}$; unit 1 to base of unit 4) comprises thinly bedded red to yellow-red silty cherts, with several small folds. In the middle part $(8.78 \mathrm{~m}$; unit 4 to middle part of unit 6) are siliceous mudstones with clay materials interbedded with yellow to reddish thin-bedded silty cherts. The upper part ( $2.4 \mathrm{~m}$; top part of unit 6 to unit 8 ) comprises grey to yellow thinly bedded cherts. Some 147 samples were selected, of which 130 were productive; 11 Follicucullus species were identified (Fig. 2B).

The Guoyuan (GY) section is $23 \mathrm{~m}$ thick, subdivided into 2 units. The section comprises yellow moderate to thickly bedded silty cherts with occasional yellow thinly bedded tuff layers. All of the 27 samples were productive and yielded 11 Follicucullus species (Fig. 2C).

The Yutouling (YTL) section is comprised of 7 units, with a total thickness of $c .27 .8 \mathrm{~m}$. The lower and middle parts $(c .20 \mathrm{~m}$; unit 1 to base of unit 4) are thick to medium-bedded yellow-purple-red silty cherts, interbedded with some thin-bedded silty cherts. In the upper part (7.2 m; top of unit 4 to base of unit 7), there are thinly bedded grey-yellow-purple silty cherts. The uppermost part (c. $0.5 \mathrm{~m}$; top of unit 7) is composed of siliceous mudstone with clay and tuff materials. Among the 103 samples collected, 33 were productive and yielded nine Follicucullus species (Fig. 2D). 


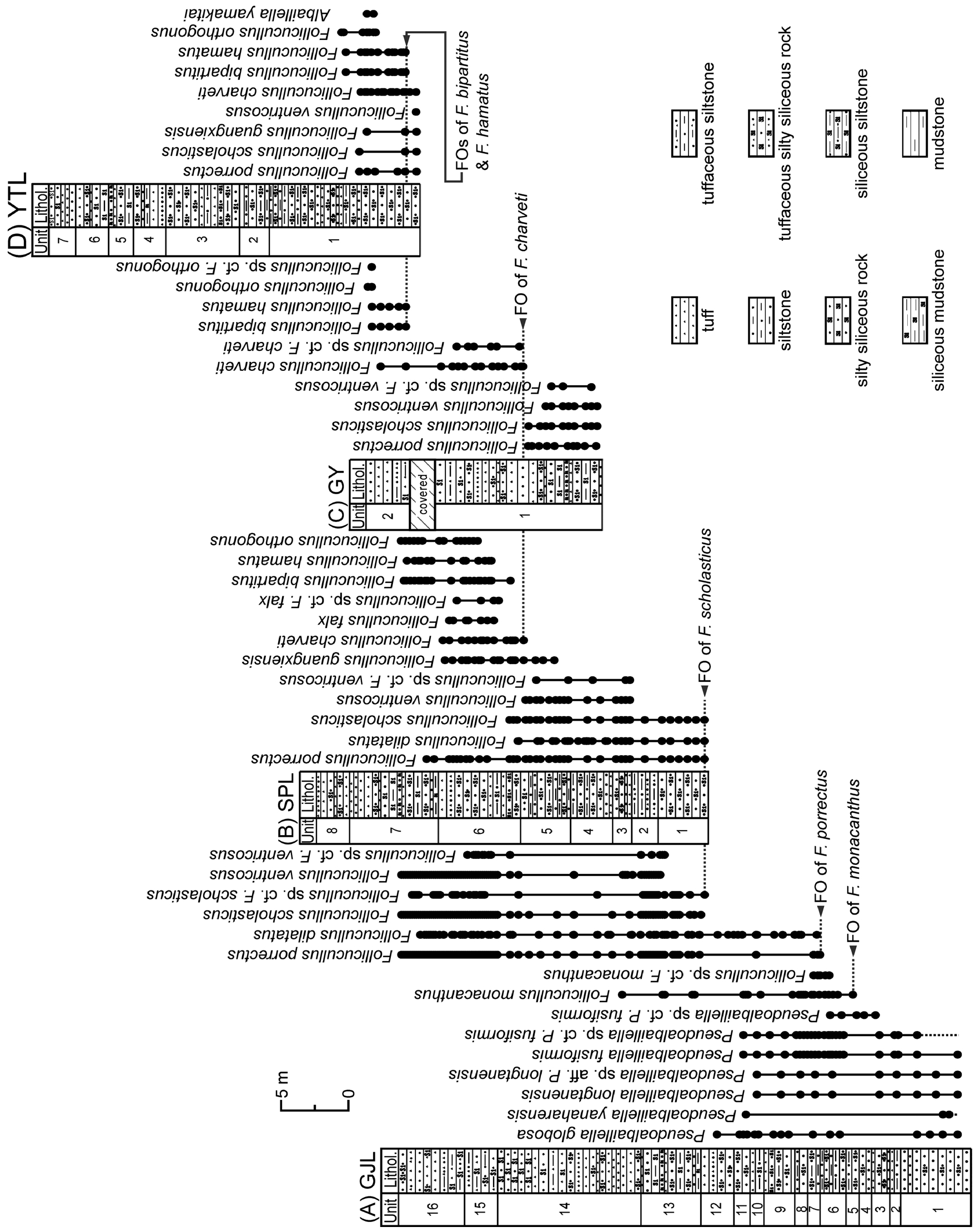


STRATIGRAPHIC AND FAUNAL CORRELATIONS OF FOLLICUCULLUS

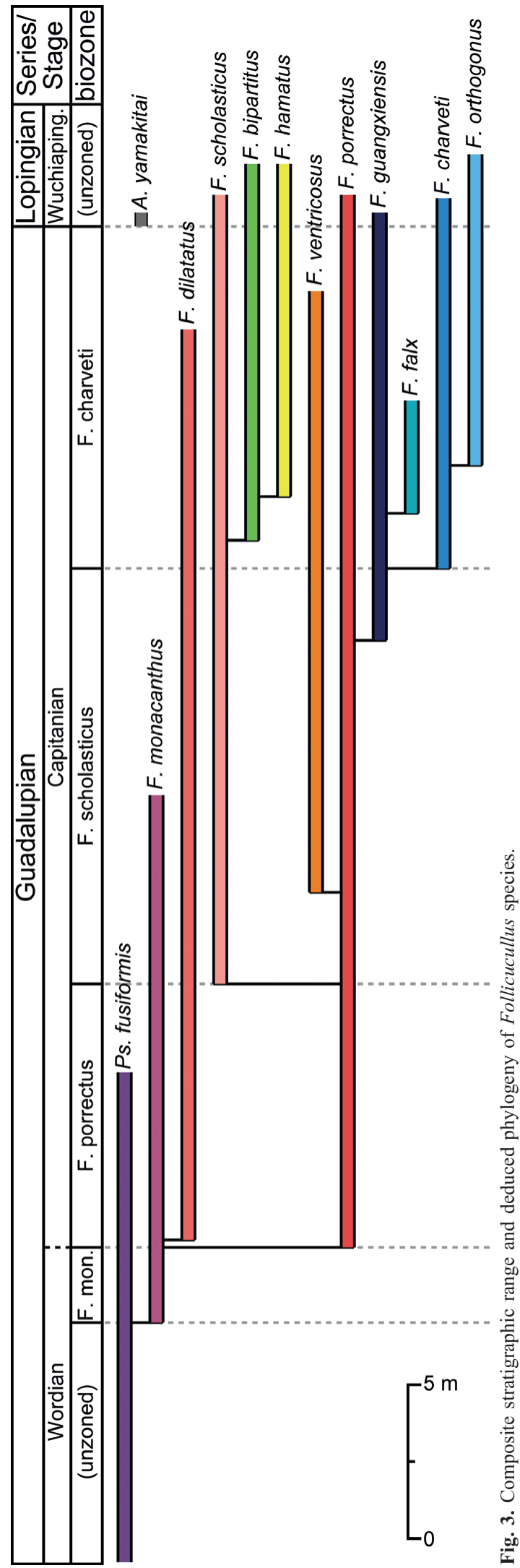

The sections were compared based on the first occurrences (FOs) of specific species, as well as the presence of species occurring continuously through a section. The Gujingling (GJL) and Sanpaoling (SPL) sections can be correlated based on the FO of F. scholasticus; the Sanpaoling and Guoyuan (GY) sections were compared based on the FO of $F$. charveti; and the Guoyuan and Yutouling (YTL) sections were compared based on the FOs of F. bipartitus and $F$. hamatus (Fig. 2). The composite stratigraphic range of Follicucullus species and related Pseudoalbaillella species was reconstructed as shown in Figure 3 , with consideration of the stratigraphic order of bioevents and morphological similarities.

The composition of Follicucullus species is nearly the same in each examined section, but some significant differences are also recognizable. For example, despite the continuous occurrence of Follicucullus in the GJL section, F. guangxiensis was not detected in this sequence. The upper part of the GJL section overlaps with the lower part of the SPL section based on biostratigraphy, but $F$. monacanthus was not found in the SPL section. In the GY section, $F$. dilatatus was absent.

\section{BIOZONES AND BIOSTRATIGRAPHY}

Based on the stratigraphic ranges of Follicucullus species, four Interval Zones are suggested for the Late Guadalupian (Wordian and Capitanian), in chronological order: the F. monacanthus, F. porrectus, F. scholasticus and F. charveti Interval Zones (Fig. 4).

\section{Follicucullus monacanthus Interval Zone}

Definition. The base of the zone is defined by the FO of F. monacanthus and the top is marked by the base of the succeeding zone, the FO of $F$. porrectus (Fig. 3).

Type section. Unit 5 to unit 6 of the GJL section.

Bioevents of Follicucullus. FO of F. monacanthus.

Remarks. The abundance and diversity of Pseudoalbaillella are higher in this Interval Zone than those of Follicucullus, with Follicucullus monacanthus, Ps. fusiformis, Ps. globosa, Ps. cf. longicornis and Ps. longtanensis being prevalent. The F. monacanthus Interval Zone is correlated with the Jinogodolella asserata and the lower part of the Jinogodolella postserrata conodont zones, as recorded in the Hubei province, China (Kuwahara et al., 2008) and, therefore, they can be correlated with the Wordian and the earliest Capitanian (Henderson et al., 2012).

Distribution. SW Japan (Ishiga, 1986a, b, 1990; Kawai \& Takeuchi, 2001); Hubei, Anhui, Jiangsu, Guizhou, and Guangxi provinces, China (Wang et al., 1994, 2006; Yu, 1996; Kuwahara et al., 1997, 2007; Yao et al., 2004; Yao \& Kuwahara, 2004; Sun \& Xia, 2006; Kametaka et al., 2009; this work); Grindstone Terrane of Central Oregon (Blome \& Reed, 1992); North Thailand (Sashida \& Salyapongse, 2002; Wonganan \& Caridroit, 2006); East Russia (Suzuki et al., 2005).

Age. Capitanian (late Guadalupian) (Fig. 4). 


\section{Follicucullus porrectus Interval Zone}

Definition. The base of the zone is defined by the FO of F. porrectus and the top is marked by the base of the succeeding zone, the FO of F. scholasticus (Fig. 3).

Type section. Unit 7 to unit 12 of the GJL section.

Bioevents of Follicucullus. FO of $F$. porrectus; FO of $F$. dilatatus.

Remarks. Follicucullus japonicus (Ishiga, 1991) is a junior synonym of $F$. porrectus Rudenko in Belyanskiy et al., 1984. The abundance and diversity of Pseudoalbaillella are lower than in the F. monacanthus zone, but Follicucullus species are equally few. The occurring species are $F$. porrectus, $F$. dilatatus, $F$. monacanthus, Ps. fusiformis, Ps. globosa, Ps. cf. longicornis and Ps. longtanensis. The F. porrectus zone is equivalent to the Ps. scalprata m. rhombothoracata zone described in Malaysia (Jasin, 1997). According to Ishiga $(1986 a, 1991)$ the FO of $F$. japonicus occurs approximately midway through the previously described F. monacanthus zone. Consequently, the F. japonicus zone defined by Ishiga (1991) is correlated with the lower part of the F. porrectus zone in this study (Fig. 4).

Distribution. Malaysia (Jasin, 1997); North Thailand (Sashida \& Salyapongse, 2002; Wonganan \& Caridroit, 2006); Central Japan (Kawai \& Takeuchi, 2001); East Russia (Suzuki et al., 2005); Guangxi, China (this work).

Age. Capitanian (late Guadalupian) (Fig. 4).

\section{Follicucullus scholasticus Interval Zone}

Definition. The base is defined by the FO of F. scholasticus and the top by the base of the succeeding zone, the FO of $F$. charveti (Fig. 3).

Type section and type horizons. Unit 1 to unit 5 of the SPL section.

Bioevents of Follicucullus. FO of F. scholasticus; FO of $F$. ventricosus; last occurrence (LO) of F. monacanthus.

Remarks. Follicucullus is abundant but not very diverse in this Interval Zone; $F$. porrectus is particularly abundant, while the species F. scholasticus, $F$. dilatatus, F. monacanthus, F. guangxiensis and $F$. ventricosus are common. The zone is correlated with the F. scholasticus-F. ventricosus Assemblage Zone of Wang et al. (2006).

Distribution. SW Japan (Ishiga, 1986a, b, 1990; Kuwahara \& Yao, 2001; Yamanaka, 2001; Yao et al., 2001); East and South China (Wang et al., 1994, 2006; Kuwahara et al., 1997, 2007; Yao \& Kuwahara, 2004; Yao et al., 2004; Sun \& Xia, 2006; this study); Grindstone Terrane of Central Oregon (Blome \& Reed, 1992); East Russia (Suzuki et al., 2005).

Age. The Follicucullus scholasticus Interval Zone is correlated with the Lepidolina kumaensis fusulina zone in the Mino belt, SW Japan (Ishiga, 1982). The L. kumaensis Zone is dated as late Capitanian (Leven, 1996; Kotylar, 2008; Kasuya et al.,
2012), although sporadic occurrences of L. kumaensis are known from the Lopingian in the South Kitakami Belt (Choi, 1970), Primorye region of Russia (Kotylar et al., 2007) and South China (Rui, 1983). Because the underlying F. charveti Interval Zone is dated to the latest Capitanian, the F. scholaticus Interval Zone is assigned here to the Middle-Late Capitanian (Fig. 4).

\section{Follicucullus charveti Interval Zone}

Definition. The base is defined by the FO of $F$. charveti and the top by the base of the succeeding zone, the FO of Albaillella yamakitai (Fig. 3).

Type section and type horizons. Albaillella yamakitai occurs only in the YTL section, but the FO of $F$. charveti is unclear in the YTL section. These two species occur throughout the YTL section. Therefore, this study does not define a type section and type horizons for the F. charveti Interval Zone.

Bioevents of Follicucullus. FO of $F$. charveti; FO of $F$. bipartitus; FO of F. falx; FO of F. hamatus; FO of F. orthogonus; LO of $F$. falx; LO of $F$. dilatatus.

Remarks. Species $F$. charveti, $F$. bipartitus, $F$. scholasticus, $F$. ventricosus, $F$. guangxiensis and $F$. orthogonus are common The F. charveti zone described here corresponds to the F. charveti zone of Sun \& Xia (2006), the F. charveti-F. bipartitus Assemblage Zone of Ishiga $(1986 a, b, 1990)$, the F. charveti-F. bipartitusF. orthogonus Assemblage Zone of Wang et al. (2006) and to the lower part of the F. charveti-Albaillella yamakitai Assemblage Zone of Kuwahara et al. (1997, 1998, 2003, 2007), Yao et al. (2001, 2004), Kuwahara \& Yao (2001) and Yao \& Kuwahara (2004).

Distribution. SW Japan (Ishiga, 1986a, b, 1990; Kuwahara \& Yao, 2001; Yao et al., 2001); East and South China (Wang \& Li, 1994; Wang et al., 1994, 2006; Kuwahara et al., 1997, 2003; Yao \& Kuwahara, 2004; Yao et al., 2004; Sun \& Xia, 2006; this work); East Russia (Suzuki et al., 2005).

Age. The F. charveti Interval Zone is defined below the FO of $A$. yamakitai whose datum is recognized below the basal Wuchiapingian (the base of the Lopingian) (Nishikane et al., 2010). Consequently, the F. charveti Interval Zone is assigned to the latest Capitanian (Fig. 4).

\section{PHYLOGENETIC MODEL OF FOLLICUCULLUS}

\section{Origin of Follicucullus}

As with the intermediate forms between Pseudoalbaillella and Follicucullus reported by De Wever et al. (2001), two specimens with transitional characters were found in our material (Pl. 1, figs 7 and 12). The specimen shown in Plate 1, figure 7 can still be classified as Pseudoalbaillella, although its symmetrical pseudothoracic flaps have degenerated into two little inflations. Some important characters of $F$. monacanthus, for example the projection on only one side of the pseudothorax, are present on the subsequent specimens (Pl. 1, fig. 12). In spite of these features, the 


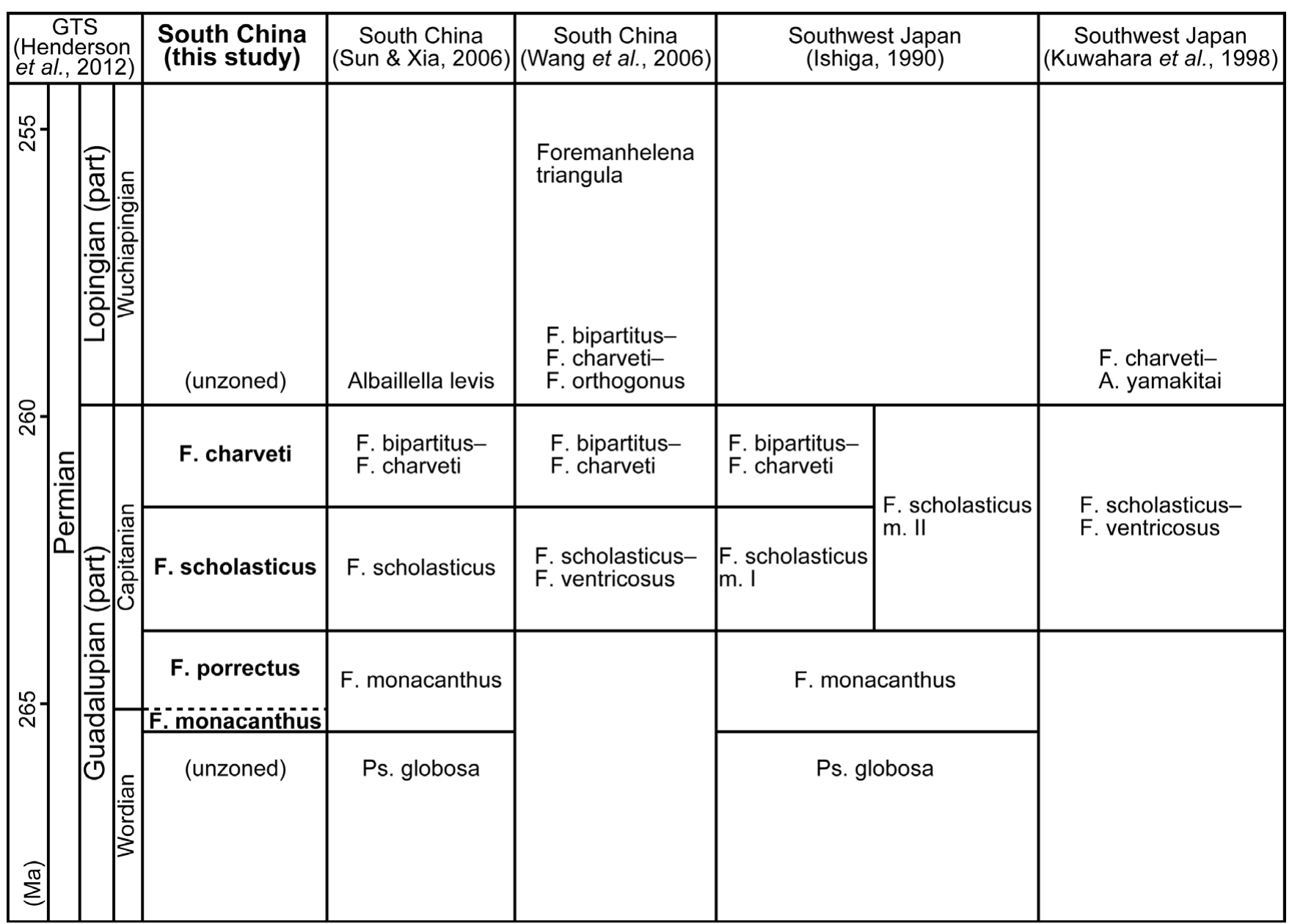

Fig. 4 . Correlation of radiolarian biozones in the Guadalupian and Lopingian. Data from Ishiga (1990), Kuwahara et al. (1998), Wang et al. (2006), Sun \& Xia (2006) and Henderson et al. (2012).

characters considered typical for Pseudoalbaillella (i.e. globular pseudothorax) are not totally obliterated. Similar specimens are also recognized from the literature: F. monacanthus in De Wever et al. (1988, pl. 1, fig. D). Ishiga (1991, p. 111) also noticed the affinity between Follicucullus and Pseudoalbaillella: 'The possession of the wing even though it is an asymmetric one, suggests connection of Pseudoalbaillella and Follicucullus probable ancestor of F. monacanthus is Pseudoalbaillella sp. cf. P. fusiformis'. De Wever et al. (2001) also pointed out the shape and size similarities of F. monacanthus and Ps. fusiformis: both have an apical cone, a pseudothorax and pseudoabdomen, and a flap on the pseudothorax. Follicucullus monacanthus primarily differs from
Ps. fusiformis in having only one pseudothoracic flap, as opposed to the pair of symmetrical flaps of PS. fusiformis. Hence, Follicucullus may have originated from Pseudoalbaillella through the species Ps. fusiformis that gave rise to F. monacanthus.

\section{Position of $F$. porrectus and $F$. dilatatus in the phylogenetic model of Follicucullus}

In our samples, $F$. porrectus and $F$. dilatatus occur almost at the same level and earlier than $F$. scholasticus. They are similar in shape with a long apical cone, a pseudothorax, an apertural spine and a very short slightly curved pseudoabdomen. The

Explanation of Plate 1. figures 1-26. Guadalupian radiolarians from the Xiaodong Town, southern Guangxi, China. The sample number and SEM photo number are given for each illustrated specimen. Scale bar $100 \mu \mathrm{m}$ for all specimens, unless otherwise specified: 1, 2, Pseudoalbaillella globosa Ishiga \& Imoto in Ishiga et al., 1982 b (1: sample GJL1-3/003, 2: sample GJL1-3/005); 3, Pseudoalbaillella yanaharensis Nishimura \& Ishiga, 1987 (sample GJL11-5/015); 4, Pseudoalbaillella sp. cf. F. longicornis Ishiga \& Imoto, 1980 (sample GJL1-8/001); 5, 6, Pseudoalbaillella fusiformis Holdsworth \& Jones, 1980 (5: sample GJL6-3/00, 6: sample GJL1-5/001); 7, Pseudoalbaillella sp. cf. P. fusiformis Holdsworth \& Jones, 1980 (sample GJL8-1/008); 8-11, Follicucullus monacanthus Ishiga \& Imoto in Ishiga et al., 1982b (8: sample GJL11-4/004, 9: sample GJL11-6/002, 10: sample GJL11-5/00, 11: sample GJL11-6/004); 12, Follicucullus sp. cf. Follicucullus monacanthus Ishiga \& Imoto in Ishiga et al., 1982b (sample GJL8-5/004); 13, Follicucullus dilatatus Rudenko in Belyanskiy et al., 1984 (sample YTL1-1/017); 14, Follicucullus sp. cf. F. dilatatus Rudenko (sample GJL115/012); 15-20, Follicucullus porrectus Rudenko in Belyanskiy et al., 1984 (15: sample SPL3-1/025, 16: sample SPL3-3/001, 17: sample GY1-1/027, 18: sample GY1-1/022, 19: sample GY1-1/023, 20: sample GY1-1/019); 21, Follicucullus sp. cf. F. porrectus Rudenko (sample GJL11-8/001); 22-24, Follicucullus ventricosus Ormiston \& Babcock, 1979 (22: sample GY1-1/008, 23: sample GY1-1/018, 24: sample GY1-1/020); 25, 26, Follicucullus sp. cf. ventricosus Ormiston \& Babcock, 1979 (25: sample SPL3-1/026, 26: sample SPL3-1/012). 


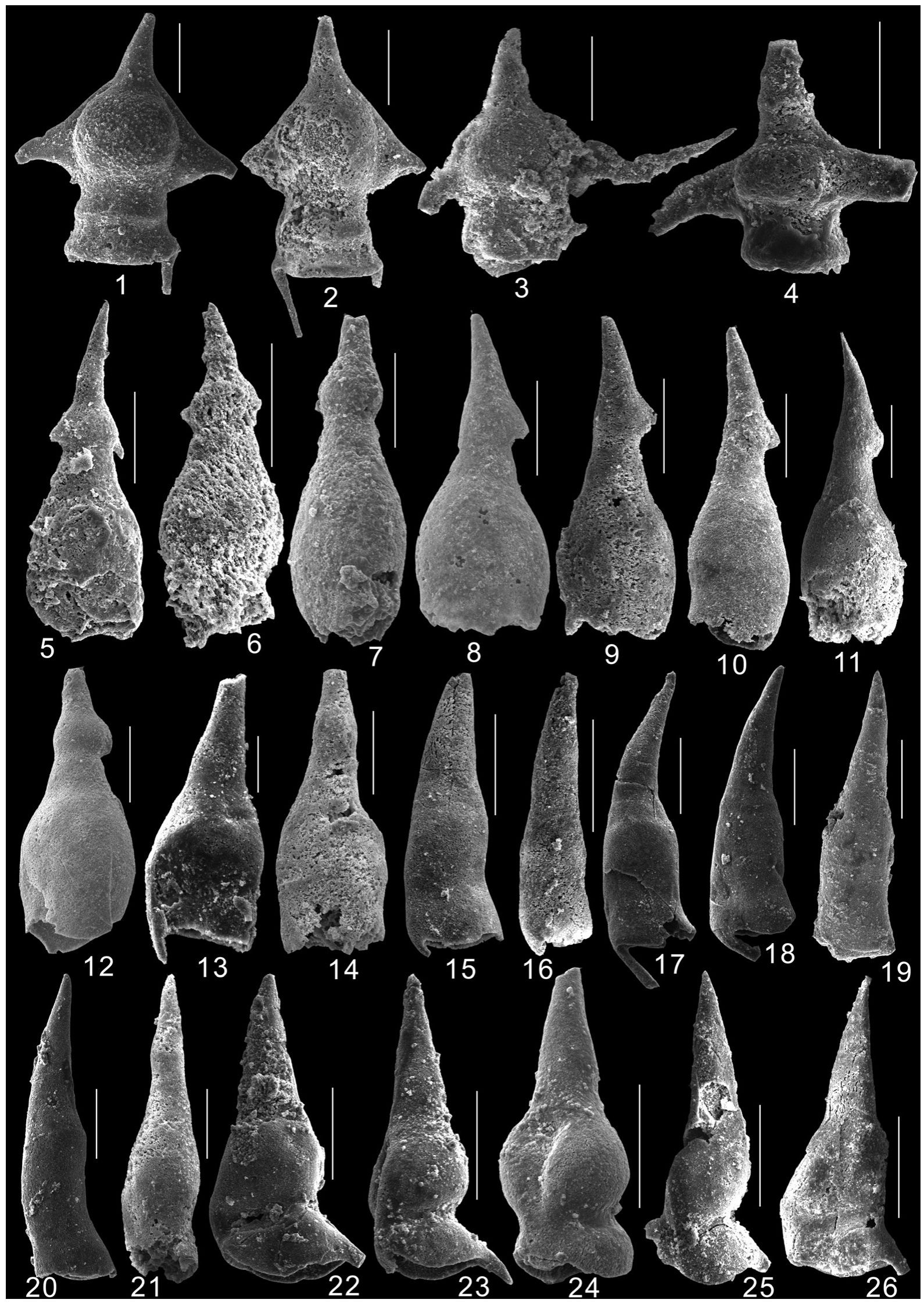


only difference is the smoother contour and slender shell of $F$. porrectus. Two transitional specimens are similar to $F$. porrectus (P1. 1, fig. 21) and $F$. dilatatus (P1. 1, fig. 14). However, they possess a slight projection on the apical cone similar to a degenerated pseudothoracic flap of $F$. monacanthus. It suggests a parallel relationship between $F$. porrectus and $F$. dilatatus, both of them deriving from $F$. monacanthus. Follicucullus scholasticus appeared slightly earlier than $F$. ventricosus. Follicucullus scholasticus has a smoother and slender shell while $F$. ventricosus has a strongly swollen pseudothorax, a sinus on the pseudothorax and a clear constriction between the pseudothorax and pseudoabdomen. Some specimens with intermediate forms between $F$. porrectus and $F$. scholasticus (Pl. 1, fig. 16) and between $F$. porrectus and $F$. ventricosus (P1. 1, fig. 26) were also found, suggesting that they all originate from F. porrectus.

\section{Origin of $F$. falx}

The diagnostic character of $F$. falx is its hatchet-shaped ventral spine (Caridroit \& De Wever, 1984). Its shape is close to that of $F$. charveti, suggesting that these two species have a clear affinity and that they are probably situated on an evolutionary continuum (Caridroit \& De Wever, 1986). Some specimens from the SPL section led Wang et al. (2012) to introduce $F$. guangxiensis. This species is rather similar to $F$. porrectus but it possesses a strong horizontal spine on the ventral side of the pseudoabdomen, which seems to indicate a transitional morphotype between $F$. porrectus and $F$. charveti. Some transitional specimens display a nearly continuous morphological change from $F$. guangxiensis to $F$. charveti (P1. 2, fig. 15). The pseudothorax of these transitional species inflated gradually to achieve an ovoid shape. A similar pattern is also recorded with the transitional specimens between $F$. guang $x$ iensis and F. falx. With the exception of the change on the pseudothorax, the ventral spine is also gradually modified into a hatchet-shaped spine. Rather than evolutionary continuity, our data support the idea that the phylogenetic position of $F$. falx is parallel to that of $F$. charveti. Accordingly, we conclude that they all originated from $F$. porrectus through F. guangxiensis.

\section{Phylogenetic model of Follicucullus}

Our results slightly modify the current ideas of the Follicucullus phylogeny, as detailed previously. Some transitional specimens we present here indicate that $F$. monacanthus originated from Ps. fusiformis. Although their taxonomic nomination is still ambiguous (e.g. Wang et al., 2012), it is the first time that
F. monacanthus is recognized as the link between the genera Pseudoalbailella and Follicucullus. From F. monacanthus the radiation of two co-existing species took place: $F$. porrectus and $F$. dilatatus. Follicucullus porrectus appears as a common ancestor of many Follicucullus species, for example $F$. hamatus and $F$. bipartitus through $F$. scholasticus, $F$. charveti and $F$. falx through $F$. guangxiensis and $F$. ventricosus. Follicucullus orthogonus unquestionably originated from $F$. charveti. The details of the inferred phylogenic relationships of Follicucullus are shown in Figure 3.

\section{CONCLUSIONS}

(1) High-resolution stratigraphic distributions of various species of the genus Follicucullus were determined for the Guadalupian-Lopingian interval.

(2) Based on the stratigraphic ranges and phylogenetic relationships of Follicucullus, four Follicucullus interval lineage zones are suggested: the F. monacanthus, F. porrectus, F. scholasticus and F. charveti Interval Zones. Previously known Permian radiolarian zones are essentially assemblage zones without discrete definition of their bases and tops. This is the first time that Interval Zones are defined.

(3) The genus Follicucullus originated from Ps. fusiformis, and its oldest species is $F$. monacanthus. Two co-existing species radiated from $F$. monacanthus: $F$. porrectus and F. dilatatus. Follicucullus porrectus is very abundant and extends from the Guadalupian into the Lopingian, thus being the ancestor of several Follicucullus lineages

\section{SYSTEMATIC PALAEONTOLOGY OF FOLLICUCULLUS}

Full synonymy lists and associated literature can be found in the Supplementary material.
Infrakingdom Rhizaria Cavalier-Smith, 2002, sensu emend. Cavalier-Smith, 2003
Phylum Retaria Cavalier-Smith, 1999
Class Polycystina Ehrenberg, 1839

Order Albaillellaria Deflandre, 1953, emend. Holdsworth, 1969 Superfamily Follicuculoidea Cheng, 1986

Family Follicucullidae Ormiston \& Babcock, 1979, emend Kozur, 1981

Genus Follicucullus Ormiston \& Babcock, 1979

Type species. Follicucullus ventricosus Ormiston \& Babcock, 1979.

Explanation of Plate 2. figures 1-21. Guadalupian radiolarians from the Xiaodong town, south Guangxi, China. The sample number and SEM photo number are given for every illustration. Scale bar $100 \mu \mathrm{m}$ for all specimens, unless otherwise specified: 1-3, Follicucullus scholasticus Ormiston \& Babcock, 1979 (1: sample GJL11-5/012, 2: sample SPL2-8/001, 3: sample SPL3-1/040); 4, Follicucullus sp. cf. F. bipartitus Caridroit \& De Wever, 1984 (sample SPL3-1/041); 5, Follicucullus bipartitus Caridroit \& De Wever, 1984 (sample SPL6-8/002); 6, Follicucullus sp. cf. F. hamatus Caridroit \& De Wever, 1984 (sample SPL6-8/002); 7, Follicucullus hamatus Caridroit \& De Wever, 1984 (sample SPL6-11/009); 8-10, Follicucullus guangxiensis Wang in Wang et al., 1992 (8: sample SPL5-1/039, 9: sample SPL5-1/035, 10: sample SPL5-1/015); 11, Follicucullus falx Caridroit \& De Wever, 1984 (sample SPL6-24/036); 12-14, Follicucullus sp. cf. F. falx Caridroit \& De Wever, 1984 (12: sample SPL6-24/029, 13: sample SPL624/063, 14: sample SPL6-24/056); 15, 16, Follicucullus charveti Caridroit \& De Wever, 1984 (15: sample GY1-1/031, 16: sample SPL6-24/030); 17, Follicucullus sp. cf. F. orthogonus Caridroit \& De Wever, 1984 (sample YTL1-1/030); 18-20, Follicucullus orthogonus Caridroit \& De Wever, 1984 (18: sample YTL1-1/034, 19: sample SPL6-22/035, 20: sample YTL1-1/035); 21, Albailella yamakitai Kuwahara, 1999 (sample YTL1-1/025). 


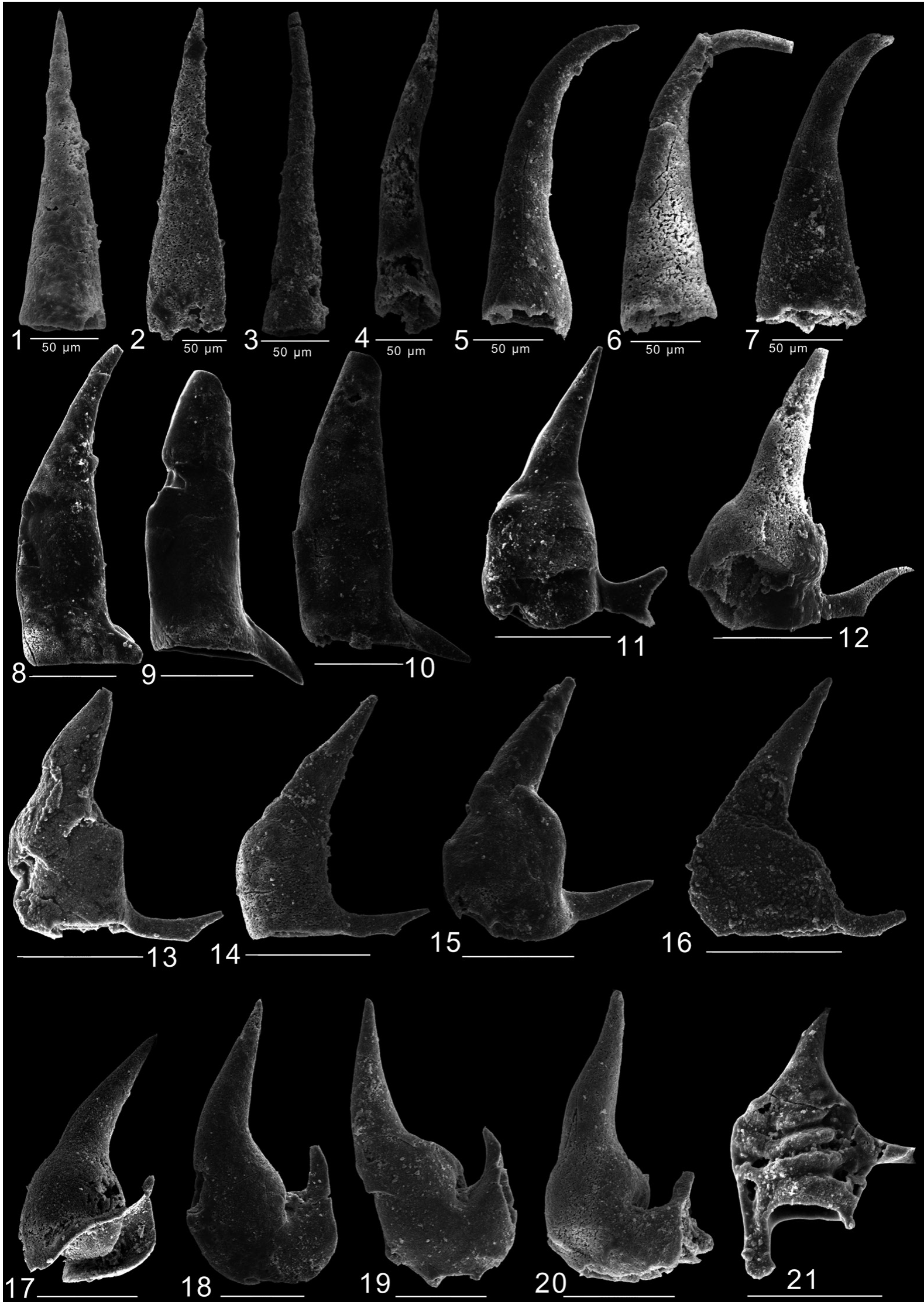


Follicucullus bipartitus Caridroit \& De Wever, 1984

(Pl. 2, fig. 5)

1984 Follicucullus bipartitus Caridroit \& De Wever: p.640, pl. 1, figs $1-3$.

Material. Over 100 complete specimens from the SPL, GY and YTL sections.

Occurrence. SW Japan, North America, SE Asia and South China.

Stratigraphic range. Guadalupian-Lopingian.

Follicucullus charveti Caridroit \& De Wever, 1984, emend Caridroit \& De Wever, 1986

(Pl. 2, figs 15, 16)

1984 Follicucullus (?) charveti Caridroit \& De Wever: p. 641, pl. 1, figs 15-22.

Material. Over 80 entire specimens from the SPL, GY and YTL sections.

Occurrence. SW Japan, North American, SE Asia, South China and New Zealand.

Stratigraphic range. Guadalupian-Lopingian.

Remarks. The specimens of this species vary between two morphological poles: the charveti-pole corresponding to specimens showing a thin and long apertural spine very similar to the holotype, while the guangxiensis-pole specimens display a less swollen pseudothorax and shorter apertural spine. Although the specimens of the guangxiensis-pole have apertural spines slightly different from the original description of $F$. charveti, they still cannot be assigned to $F$. guangxiensis because their apical cone is straighter and the pseudothorax is much less to not at all swollen.

Follicucullus dilatatus Rudenko in Belyanskiy et al., 1984 (Pl. 1, fig. 13)

1984 Follicucullus dilatatus Rudenko in Belyanskiy et al.: p. 54 pl. 8, figs 6-7

Material. More than 180 entire specimens from the GJL section.

Occurrence. Worldwide.

Stratigraphic range. Guadalupian-Lopingian.

Remarks. Follicucullus dilatatus and $F$. porrectus mostly differ in the shape of their pseudothorax, which is larger in $F$. dilatatus. In our material, specimens defined as $F$. dilatatus show a continuous change from typical dilatatus- to porrectus-like morphology. The porrectus-like specimens belong to $F$. dilatatus because of their wider pseudothorax, much wider than in $F$. porrectus. They reveal an evolutionary trend from $F$. porrectus to $F$. dilatatus.

\section{Follicucullus falx Caridroit \& De Wever, 1984}

(Pl. 2, fig. 11)

1984 Follicucullus falx Caridroit \& De Wever : p.641, pl. 1, figs $4-6$.

Material. More than 20 entire specimens from the Sanpaoling section.

Occurrence. North America and SW China.

Stratigraphic range. Guadalupian-Lopingian.

Follicucullus sp. cf. Follicucullus falx Caridroit \& De Wever, 1984 (P1. 2, figs 12-14)

Material. Seven entire specimens from the SPL section.

Occurrence. South China.

Stratigraphic range. Guadalupian-Lopingian.

Remarks. The specimens of this species cannot be assigned to $F$. falx because their spine is not bifide. They have a wider apertural spine than $F$. charveti, which is the initiation of the bifide spine of $F$. falx. Some of them resemble $F$. guangxiensis in their straight to slightly curved apical cone, slightly more inflated and shorter pseudothorax and aperture spines protruding horizontally.

Follicucullus guangxiensis Wang in Wang et al., 2012

$$
\text { (P1. 2, figs 8-10) }
$$

2012 Follicucullus guangxiensis Wang in Wang et al. :p.108, pl. 20, figs $8,29,30$, pl. 21, figs 1, 2, 4-6.

Material. Twenty-four entire specimens from the SPL and YTL sections.

Occurrence. South China (Wang, 2012; this work).

Stratigraphic range. Upper Guadalupian-lowest Lopingian.

Follicucullus hamatus Caridroit \& De Wever, 1984

(Pl. 2, fig. 7)

1984 Follicucullus hamatus Caridroit \& De Wever: p. 642, pl. 1, figs 7-9.

Material. Forty-one entire specimens from the SPL, GY and YTL sections. 
Occurrence. SW Japan, North America and South China.

Stratigraphic range. Guadalupian-Lopingian.

Follicucullus monacanthus Ishiga \& Imoto in Ishiga et al., $1982 b$ (Pl. 1, figs 8-12)

1982 Follicucullus monacanthus Ishiga \& Imoto in Ishiga et al.: p. 642 , pl. 4, figs $15-17,21-23$.

Material. Thirty-two entire specimens from the GJL section.

Occurrence. SW Japan, North America, Far East, SE Asia and South China.

Stratigraphic range. Guadalupian.

Remarks. The present species is assigned to Follicucullus. The number of wings is a generic criterion: Pseudoalbaillella is characterized by having two wings, which are absent in Follicucullus. Follicucullus monacanthus displays only a ventral wing and therefore seems transitional between $F$. fusiformis, which bears strong dorsal and ventral wings, and $F$. porrectus, bearing no wing. However, other morphological elements, such as pseudoabdomen, relate $F$. monacanthus more closely to $F$. fusiformis. Therefore, F. monacanthus, bearing a unique wing, should belong neither to Follicucullus nor to Pseudoailbaillella but to a different genus marked by a unique wing. It seems therefore more accurate to attribute this species to 'Para'follicucullus. However, in the absence of a complete revision of this taxonomy, we have decided here to follow the traditional view and consider this species as belonging to the genus Follicucullus.

\section{Follicucullus sp. cf. Follicucullus monacanthus Ishiga \& Imoto in Ishiga et al., $1982 \mathrm{~b}$}

(P1. 1, fig. 12)

Material. Five entire specimens from the GJL section.

Occurrence. South China.

Stratigraphic range. Guadalupian.

Remarks. This species is related to $F$. monacanthus in the shape of the wings and the projection on the apical cone. However, in $F$. monacanthus the wings are degenerated or absent and the pseudothorax is flat, weakly inflated.

Follicucullus orthogonus Caridroit \& De Wever, 1984 (Pl. 2, figs 18-20)

1984 Follicucullus orthogonus Caridroit \& De Wever : p. 276, pl. 1, figs 23-29.

Material. Forty-two entire specimens from the SPL, GY and YTL sections.
Occurrence. North America, South Japan, South China.

Stratigraphic range. Guadalupian-Lopingian.

Follicucullus sp. cf. Follicucullus orthogonus Caridroit \& De Wever, 1984

(Pl. 2, fig. 17)

Material. One entire specimen from the GY section.

Occurrence. South China.

Stratigraphic range. Guadalupian-Lopingian.

Remarks. The present specimen is consistent with $F$. orthogonus in most features: a straight or slightly curved apical cone, a moderately inflated pseudothorax, a pseudoabdomen with horizontal aperture and upturned aperture spines. However, our specimen has a peculiar aperture, which splits horizontally from the bottom. It may be a transitional species from $F$. charveti to F. orthogonus.

Follicucullus porrectus Rudenko in Belyanskiy et al., 1984 (P1. 1, figs 15-20)

1984 Follicucullus porrectus Rudenko in Belyanskiy et al.: p. 55, pl. 8, figs 3,10 .

Material. Some 319 entire specimens from the GJL, SPL, GY and YTL sections.

Occurrence. Worldwide.

Stratigraphic range. Guadalupian-Lopingian.

Remarks. Based on our material and on the literature, three morphotypes can be recognized for this species: (i) the first type is symmetrical, has sides of the apical zone that concave outwards, a bottleneck transition between the apex and pseudothorax, a slightly concave-outward pseudothorax and the transition between the pseudothorax and pseudoabdomen marked by a constriction; (ii) the second type is also symmetrical with straight divergent apical sides, a sharply angulated transition between the apex and pseudothorax, a straight pseudothorax and no constriction at the transition between pseudothorax and pseudoabdomen; (iii) the third type corresponds to the holotype of the species - it is asymmetrical, with the apex slightly concave outward on one side and more or less straight on the other, an angulated transition with the pseudothorax on one side, a straight pseudothorax and none to a slight constriction between the pseudothorax and pseudoabdomen. This third morphology is the most abundant. The first and third types are described in Belyanskiy et al., 1984. In 1991, Ishiga described $F$. japonicus, proved later to be a synonym of $F$. porrectus. The holotype of $F$. japonicus is close to figures 4 and 5 illustrated in Belyanskiy et al., 1984, which can be related to our third type.

For these three morphologies, those specimens that are longer and thinner with a smoother transition between the apical cone and 
pseudothorax are identified as F. scholasticus. However, specimens of the first type with a more elongated shape, a longer and thinner apical cone and a marked transition between the apical cone and pseudothorax are identified as F. elongatus by Spiller, 2002.

Follicucullus scholasticus Ormiston \& Babcock, 1979 (P1. 2, figs 1-3)

1979 Follicucullus scholasticus Ormiston \& Babcock: pl. 1, figs $1-5$.

Material. Some 269 entire specimens from the GJL, SPL, GY and YTL sections.

Occurrence. Worldwide.

Stratigraphic range. Guadalupian-Lopingian.

Remarks. This species displays important intraspecific variations in our material, ranging from wider specimens (Pl. 2, figs 1-2) to slimmer ones (Pl. 2, fig. 3).

Follicucullus sp. cf. Follicucullus scholasticus

Ormiston \& Babcock, 1979

(Pl. 1, fig. 12)

Material. Three entire specimens from the GJL section.

Occurrence. South China (this work).

Stratigraphic range. Guadalupian-Lopingian.

Remarks. The curved apical cone distinguishes this species from both F. scholasticus and F. bipartitus in being transitional between these two species: more curved than scholasticus but not sufficiently curved to be identified as bipartitus.

Follicucullus ventricosus Ormiston \& Babcock, 1979

(P1. 1, figs 22-24)

1979 Follicucullus ventricosus Ormiston \& Babcock: pl. 1, figs $6-14$.

Material. More than 250 entire specimens from the GJL, SPL, GY and YTL sections.

Occurrence. Worldwide.

Stratigraphic range. Guadalupian-Lopingian.

Follicucullus sp. cf. Follicucullus ventricosus Ormiston \& Babcock, 1979

(P1. 1, figs 25 and 26)

1981 Follicucullus ventricosus Ormiston \& Babcock; Takemura \& Nakaseko: pl. 34, fig. 7.
Material. More than 100 entire specimens from the GJL, SPL and GY sections.

Occurrence. South China (this work).

Stratigraphic range. Guadalupian.

Remarks. Some specimens differ from the holotype of $F$. ventricosus in having a longer pseudoabdomen and a weaker constriction between the pseudothorax and pseudoabdomen. This species can also be compared to $F$. porrectus both in the apical cone and pseudothorax, but the latter has a strong constriction between the pseudothorax and apertural skirt, and a longer skirt compared with the weak apertural skirt of $F$. porrectus.

\section{ACKNOWLEDGEMENTS}

This work was supported by NSFC (40839903), Ministry of Education of China (20110145130001), and 111 Project (Grant No. B08030). Lei Zhang was funded by the European ERASMUS MUNDUS External Windows programme for a year at the University Lille 1. The authors thank Wang Weijie and Zhao Duanchang for sample preparation, Wu Jun, Liu Guichun, Lei Yong, Yang Wenqiang and Marie-Beatrice Forel for their constructive suggestions during writing. The authors are deeply grateful to Suzuki Noritoshi (Tohoku University) and Paulian Dumitrica for critical comments and valuable suggestions which improved the paper considerably. This paper benefited from editing by Claire Allen of the British Antarctic Survey.

Manuscript received 30 April 2014

Manuscript accepted 30 April 2014

Scientific editing by Claire Allen

\section{REFERENCES}

Belyanskiy, G.S., Nikitina, A.P. \& Rudenko, V.S. 1984. O Sebuchsrskoy svite Primor'ya. In Mun, N.S. (Ed.), Novyie Dannyie po Detal'noi Biostratigrafii Fanerozoya Dal'nego Vostoka. Dan'nevostochnogo Nauchnogo Tsentra Akademiya Nauk SSSR, 18: 43-57.

Blome, C.D. \& Reed, K.M. 1992. Permian and Early (?) Triassic radiolarian faunas from the Grindstone Terrane, central Oregon. Journal of Paleontology, 66: 351-383.

Bureau of Geology and Mineral Ressources of Guangxi Autonomous Region 1997. Stratigraphy (Lithostratigraphy) of Guangxi Zhuang Autonomous Region. CUG Press, Wuhan, 310pp. [in Chinese].

Caridroit, M. \& De Wever, P. 1984. Description de quelques nouvelles especes de Follicucullidae et d'Entactinidae (Radiolaires polycystines) du Permien du Japon. Geobios, 17: 639-644.

Caridroit, M. \& De Wever, P. 1986. Some Late Permian radiolarians from pelitic rocks of the Tatsuno Formation (Hyogo Prefecture), Southwest Japan. Marine Micropaleontology, 11: 55-90.

Cavalier-Smith, T. 1999. Principles of protein and lipid targeting in secondary symbiogenesis: euglenoid, Dinoflagellate, and Sporozoan plastid origin and the Eukaryote family tree. Journal of Eukaryotic Microbiology, 46: 347-366.

Cavalier-Smith, T. 2002. The phagotrophic origin of eukaryotes and phylogenetic classification of Protozoa. International Journal of Systematic and Evolutionary Microbiology, 52: 297-354.

Cavalier-Smith, T. 2003. Protist phylogeny and the high-level classification of Protozoa. European Journal of Protistology, 39: 338-348. 
Cheng, Y. 1986. Taxonomic studies on Upper Paleozoic Radiolaria. National Museum of Natural Science, Special Publication, 1: 1-213.

Choi, D.R. 1970. On some Permian fusulinids from Iwaizaki, N.E. Japan. Memoir Faculty of Science, Hokkaido University Series, 4, 14: 18131825.

Deflandre, G. 1953. Radiolaires Fossiles. In Grassé, P.P. (Ed.), Traité de Zoologie. Masson, Paris, 1: 389-436.

De Wever, P., Bourdillon-de-Grissac, C. \& Bechennec, F. 1988. Permian age from radiolarites of the Hawasina nappes, Oman Mountains. Geology, 16: 912-914.

De Wever, P., Dumitrica, P., Caulet, J.P., Nigrini, C. \& Caridroit, M. (Eds) 2001. Radiolarians in the Sedimentary Record. Gordon and Breach, Amsterdam, 533pp.

Ehrenberg, C.G. 1839. Uber die Bilding der Kreidefelsen und des Kreidemergels durch unsichibare Organismen. Abhandlungen der königlichen Akademie der Wissenschaften zu Berlin, Jahre, 1838: 59147. [In German].

Feng, Q.L. \& Liu, B.P. 1993. Permian radiolarias on southwest Yunnan. Earth Science-Journal of China University of Geosciences, 18: $553-564$.

Henderson, C.M., Davydov, V.I. \& Wardlaw, B.R. 2012. The Permian Period. In Gradstein, F.M., Ogg, J.G., Schimtz, M. \& Ogg, G. (Eds), The Geologic Time Scale 2012. Elsevier, Amsterdam, 653-679.

Holdsworth, B.K. 1969. The relationship between the genus Albaillella Deflandre and the ceratoikiscid Radiolaria. Micropaleontology, 15: 230-236.

Ishiga, H. 1982. Late Carboniferous and Early Permian radiolarians from the Tamba Belt, Southwest Japan. Earth Science (Chikyu Kagaku), 36: 333-339.

Ishiga, H. 1986a. Late Carboniferous and Permian radiolarian biostratigraphy of Southwest Japan. Journal of Geosciences, Osaka City University, 29: 89-100.

Ishiga, H. 1986b. Radiolarian biostratigraphy of the Japanese Permian. Proceedings - North American Paleontological Convention, 4: A21.

Ishiga, H. 1990. Paleozoic radiolarians. In Ichikawa, K., Mizutani, S., Hara, I., Hada, S. \& Yao, A. (Eds), Pre-Cretaceous Terranes of Japan. Publication of IGCP 224, 285-295.

Ishiga, H. 1991. Description of a new Follicucullus species from Southwest Japan. Memoirs of the Faculty of Science, Shimane University, 25: 107-118.

Ishiga, H. \& Imoto, N. 1980. Some Permian radiolarians in the Tamba District, Southwest Japan. Earth Science (Chikyu Kagaku), 34: 333-345.

Ishiga, H., Kito, T. \& Imoto, N. 1982a. Late Permian radiolarian assemblages in the Tamba District and an adjacent area, Southwest Japan. Earth Science (Chikyu Kagaku), 36: 10-22.

Ishiga, H., Kito, T. \& Imoto, N. 1982b. Middle Permian radiolarian assemblages in the Tamba District and an adjacent area, southwest Japan. Earth Sciences (Chikyu Kagaku), 36: 272-281.

Ito, T., Zhang, L., Feng, Q.L. \& Matsuoka, A. 2013. Guadalupian (Middle Permian) radiolarian and sponge spicule faunas from the Bancheng Formation of the Qinzhou Allochthon, South China. Journal of Earth Science, 24: 145-156.

Jasin, B. 1997. Permo-Triassic radiolaria from the Semanggol Formation, northwest Peninsular. Journal of Asian Earth Sciences, 15: 43-53.

Kametaka, M., Nagai, H., Zhu, S., Qi, D. \& Takebe, M. 2009. Middle Permian radiolarians from Anmenkou, Chaohu, Northeastern Yangtze platform, China. Island Arc, 18: 108-125.

Kasuya, A., Isozaki, Y. \& Igo, H. 2012. Constraining paleo-latitude of a biogeographic boundary in mid-Panthalassa: fusuline province shift on the Late Guadalupian (Permian) migrating seamount. Gondwana Research, 21: 611-623.

Kawai, M. \& Takeuchi, M. 2001. Permian radiolarians from the Omi area in the Hida-gaien Tectonic Zone, central Japan. News of Osaka Micropaleontologists (NOM), Special Volume, 12: 23-32.
Kotylar, G.V. 2008. Permskaya Sistema. In Zhamoida, A.I. \& Petrov, O.V. (Eds), Sostoyanie Izuchennosti Stratigrafii Dokembriya I Faunerozoya Rossii. Zapadochi Dal'neyshikh Issledovaniy, VSEGEI, 38: 69-76.

Kotylar, G.V., Shen, S.Z., Kossovaya, O.L. \& Zhuravlev, A.V. 2007. Middle Permian (Guadalupian) biostratigraphy in South Primorye, Russian Far East and correlation with Northeast China. Palaeoworld, 16: $173-189$.

Kozur, H. 1981. Albaillellidae (Radiolaria) aus dem Unterperm des Vorurals. Geologisch-Paläontologische Mitteilungen Innsbruck, 10: 263-274.

Kuwahara, K. 1999. Albaillella (Albaillellaria, Radiolaria). Journal of Geosciences, Osaka City University, 42, 85-101.

Kuwahara, K. \& Yao, A. 2001. Late Permian radiolarian faunal change in bedded chert of the Mino Belt, Japan. News of Osaka Micropaleontologists (NOM), Special Volume, 12: 13-22.

Kuwahara, K., Yao, A. \& An, T. 1997. Paleozoic and Mesozoic complexes in the Yunnan area, China; (Part 1), Preliminary report of Middle-Late Permian radiolarian assemblages. Journal of Geosciences, Osaka City University, 40: 37-49.

Kuwahara, K., Yao, A. \& Yamakita, S. 1998. Reexamination of Upper Permian radiolarian biostratigraphy. Earth Science (Chikyu Kagaku), 52: 51-64.

Kuwahara, K., Yao, A., Ezaki, Y., Liu, J., Hao, W. \& Kuang, G. 2003. Occurrence of Late Permian radiolarians from the Chituao section, Laibin, Guangxi, China. Journal of Geosciences, Osaka City University, 46: $13-23$.

Kuwahara, K., Yao, A., Yao, J. \& Wang, X. 2007. Permian radiolarians from the Gufeng Formation of the Tongling area, Anhui province, China. Journal of Geosciences, Osaka City University, 50: 35-54.

Kuwahara, K., Yao, A., Yao, J., Feng, S., Ji, Z. \& Yao, H. 2008. Findings of Middle Permian radiolarian and conodont fossils from the Gufeng Formation of the Zigui area, Hubei Province, China. Journal of Geosciences, Osaka City University, 51: 9-19.

Leven, E.Y. 1996. The Midian stage of the Permian and its boundaries. Stratigraphy and Geological Correlation, 4, 54-551.

Nishikane, Y., Kaiho, K., Takahashi, S., Henderson, C.M., Suzuki, N. \& Kannno, M. 2010. The Guadalupian-Lopingian boundary (Permian) in a pelagic sequence from Panthalassa recognized by integrated conodont and radiolarian biostratigraphy. Marine Micropaleontology, 78: 84-95.

Nishimura, K. \& Ishiga, H. 1987. Radiolarian biostratigraphy of the Maizuru Group in Yanahara area, Southwest Japan. Memoirs of the Faculty of Science, Shimane University, 21: 169-188.

Ormiston, A. \& Babcock, L. 1979. Follicucullus, new radiolarian genus from the Guadalupian (Permian) Lamar Limestone of the Delaware Basin. Journal of Paleontology, 53: 328-334.

Rui, L. 1983. On the Lepidolina kumaensis fusulinacean fauna. Bulletin of Nanjing Institute of Geology and Palaeontology, Academia Sinica, 6, 249-270.

Sashida, K. \& Salyapongse, S. 2002. Permian radiolarian faunas from Thailand and their paleogeographic significance. Journal of Asian Earth Sciences, 20: 691-701.

Spiller, F.C.P. 2002. Radiolarian biostratigraphy of Peninsular Malaysia and implications for regional palaeotectonics and palaeogeography. Palaeontographica Abteilung A- Palaozoologie-Stratigraphie, 266: $1-91$.

Sun, D. \& Xia, W. 2006. Identification of the Guadalupian-Lopingian boundary in the Permian in a bedded chert sequence, south China. Palaeogeography, Palaeoclimatology, Palaeoecology, 236: 272-289.

Suzuki, N., Kojima, S. et al. 2005. Permian radiolarian faunas from chert in the Khabarovsk complex, Far East Russian and the age of each lithologic unit of the Khabarovsk complex. Journal of Paleontology, 79: 687-701. 
Takemura, A. \& Nakaseko, K. 1981. A new Permian radiolarian genus from the Tamba Belt, Southwest Japan. Transactions and Proceedings of the Palaeontological Society of Japan. New Series, 124: 208-214.

Wang, Y.J. \& Li, J.X. 1994. Discovery of the Follicucullus bipartitusFollicucullus charveti Radiolarian Assemblage Zone and its geological significance. Acta Micropalaeontologica Sinica, 11: 201-212.

Wang, Y.J., Cheng, Y. \& Yang, Q. 1994. Biostratigraphy and systematics of Permian radiolarians in China. Palaeoworld, 4: 172-202.

Wang, Y.J., Luo, H., Kuang, G.D. \& Li, J. 1998. Late Devonian-Late Permian strata of cherty facies at Xiaodong and Bancheng Counties of the Qinzhou area, SE Guangxi. Acta Micropalaeontologica Sinica, 15: 351-366. [In Chinese with English abstract].

Wang, Y.J., Yang, Q. \& Cheng, Y. 2006. Lopingian (Upper Permian) radiolarian biostragraphy of South China. Palaeoworld, 15: 31-53.

Wang, Y.J., Luo, H. \& Yang, Q. (Eds) 2012. Late Paleozoic Radiolarians in the Qinfang Area, Southeast Guangxi. China University Science Technical Press, Hefei, 127pp.

Wonganan, N. \& Caridroit, M. 2006. Middle to Upper Permian radiolarian faunas from chert blocks in Pai area, northwestern Thailand. Eclogae Geologicae Helvetiae, 99(Suppl.): 133-139.
Xia, W.C., Zhang, N., Kakuwa, Y. \& Zhang, L.L. 2005. Radiolarian and conodont biozonation in the pelagic Guadalupian-Lopingian boundary interval at Dachongling, Guangxi, South China, and mid-upper Permian global correlation. Stratigraphy, 2, 217-238.

Yamanaka, M. 2001. Permian radiolarian biostratigraphy and radiolarian morphological change in bedded chert sequence of the Tamba Terrane in Sasayama area. News of Osaka Micropaleontologists (NOM), Special Volume, 12: 13-22.

Yao, A. \& Kuwahara, K. 2004. Radiolarian fossils from the PermianTriassic of China. News of Osaka Micropaleontologists (NOM), Special Volume, 13: 29-45.

Yao, A., Kuwahara, K., Ezaki, Y., Liu, J. \& Hao, W.C. 2004. Permian radiolarians from the Qinfang Terrane, south China, and its geological significance. Journal of Geosciences, Osaka City University, 47: 71-83.

Yao, J., Yao, A. \& Kuwahara, K. 2001. Upper Permian biostratigraphic correlation between conodont and radiolarian zones in the TambaMino Terrane, Southwest Japan. Journal of Geosciences, Osaka City University, 44: 97-119.

Yu, J. 1996. Permian radiolarian biostratigraphy in the Guizhou area, China. Journal of Geosciences, Osaka City University, 39: 123-135. 